\title{
The effects of afforestation and cultivation on water yield in the Andean páramo
}

\author{
Wouter Buytaert $^{\mathrm{a}, \mathrm{b}, *}$, Vicente Iñiguez $^{\mathrm{b}}$, Bert De Bièvre ${ }^{\mathrm{c}}$ \\ ${ }^{a}$ Laboratory for Soil and Water Management, Katholieke Universiteit Leuven, Belgium \\ ${ }^{\mathrm{b}}$ Programa para el Manejo del Agua y del Suelo, Universidad de Cuenca, Ecuador \\ ${ }^{\mathrm{c}}$ International Potato Center-CONDESAN, Proyecto Páramo Andino, Quito, Ecuador
}

\begin{abstract}
Over the last decades, the Andean highlands of Ecuador have been characterised by intense afforestation efforts, in order to increase the economic return of less viable agricultural areas, reduce erosion and, more recently, to sequestrate atmospheric carbon. Afforestation with Pinus species is widespread in the high altitudinal grasslands known as páramos. The impact of Pinus patula afforestation on the water yield is studied and compared to the more common practice of intensive grazing and potato cultivation in four microcatchments in the Paute river basin in south Ecuador. Two catchments are covered with natural grassland vegetation, one is converted to pine forest, and one is drained, partly intensively grazed, and partly cultivated with potatoes. The results indicate that afforestation with P. patula reduces the water yield by about $50 \%$, or an average of $242 \mathrm{~mm} \mathrm{year}^{-1}$. The water yield of the cultivated catchment is very similar to that of the natural catchments, but analysis of the flow duration curves suggests a faster response and a loss of base flow. These effects may have important implications for a sustainable management of the páramo ecosystem, given that the páramo is the major water supplier for the Andean highlands.
\end{abstract}

(C) 2007 Elsevier B.V. All rights reserved.

Keywords: Hydrological response; Afforestation; Pinus patula; Water yield; Páramo; Flow duration curves

\section{Introduction}

\subsection{Afforestation in the Andes}

During the last decades, afforestation has been a common practice in the Ecuadorian highlands. In the lower regions of the páramo grasslands (3500-4000 $\mathrm{m}$ a.s.1.), Pinus radiata and Pinus patula plantations have become widespread. Despite the low growth rate at this altitude (above $3500 \mathrm{~m}$ ), pine plantations were considered an effective way to improve the economic viability of the páramo, which is otherwise mainly used for extensive cattle grazing. Pine forests are used for timber production, erosion reduction and mushroom harvesting (Farley et al., 2004). Since the United Nations Framework Convention on Climate Change there has been increasing interest in the potential for páramo afforestation to sequester $\mathrm{CO}_{2}$ from the atmosphere.

Despite the potential gains, pine afforestation in the páramo is seriously questioned because of the unique ecosystem that

\footnotetext{
* Corresponding author. Present address: Environmental Sciences, Lancaster University, LA1 4YQ Lancaster, UK. Tel.: +44 1524 593894; fax: +441524593985 .

E-mail address: w.buytaert@lancaster.ac.uk (W. Buytaert).
}

exists there. About $60 \%$ of the páramo vegetation is endemic. It has adapted to the specific physiochemical and climatic conditions, such as the low atmospheric pressure, intense ultraviolet radiation, and the drying effects of wind (Luteyn, 1992). Introduction of exotic species must therefore be considered very carefully to avoid a loss of biodiversity (Hofstede et al., 2002).

Furthermore, the effectiveness of $\mathrm{C}$ sequestration by pine forests in the páramo is uncertain. Many páramo soils contain elevated amounts of organic C, up to 40\% (Poulenard et al., 2002; Buytaert et al., 2005b). Pine plantations are known to alter the chemical and microbial composition of the páramo soil, through addition of nutrients in litter and the introduction of foreign microbial species such as Ectomycorrhizal fungi (Chapela et al., 2001). Combined with an elevated water consumption and thus a lower soil water content, these effects favour organic matter decomposition and may result in a lower $\mathrm{C}$ content. Reductions of up to $60 \%$ were observed in dry páramos of Cotopaxi, north Ecuador (Farley and Kelly, 2004; Farley et al., 2004), although these soils contain less C (2.8\%) than many other and wetter páramos (e.g.,Colmet-Daage et al., 1967; Poulenard et al., 2003; Buytaert et al., in press). These effects reduce the usefulness of pine forests as a $\mathrm{C}$ sequestration method. 
Finally, pine plantations may reduce water yield and alter the flow regime in rivers descending from the páramo. Over the last decades, several publications have reviewed the impact of forestry activities on the hydrological response (e.g., Bosch and Hewlett, 1982; Bruijnzeel, 2004; Brown et al., 2005; Farley et al., 2005; Adams and Fowler, 2006). It is generally accepted that total water consumption of forests is larger than that of short vegetation such as shrublands and grasslands. Forests generally have a higher leaf area index and roughness, and a deeper and better-developed root system, resulting in a higher transpiration. Interception and subsequent evaporation from the canopy and the litter layer also tends to be higher in forests (Farley et al., 2005). In coniferous forests, interception losses may reach $24 \%$ and more (Le Maitre et al., 1999).

However, the magnitude of the change in water yield due to afforestation can vary considerably, depending on climatic conditions, the type of original and replaced vegetation, its age, and the type of activity (Bosch and Hewlett, 1982). Factors such as the total forested area and tree density have an impact as well and are not always easy to determine. Changes in water yield also show a strong time variability, with a trend that is closely related to the life cycle of the tree species. At age zero little change is observed, resulting only from the planting process, though this can be significant where planting is associated with ditching (Roberts and Harding, 1996). The impact then increases gradually with the growth of the trees. When the forest reaches maturity, evapotranspiration tends to decrease again. The maximum decrease is typically observed at a plantation age of 26-30 years (Farley et al., 2005).

The impact of afforestation on the timing and seasonality of streamflow is more ambiguous. The regulating capacity of the vegetation is generally very small compared to the soil and thus soil physical properties play a major role (Brown et al., 2005). Forests are generally known for a high soil infiltration capacities, enhancing base flow. However, soil destruction during the afforestation process, e.g. by heavy machinery, may hinder infiltration and stimulate surface runoff and further decrease low flows. On the long term, forest soils may regenerate, even up to a point where infiltration is higher than before afforestation. However, the idea that these physical soil improvements reduce overland flow sufficiently to compensate for the extra water used by the forest is not sustained by field experiments (Bruijnzeel, 2004; Brown et al., 2005). Accordingly, Farley et al. (2005) concluded that afforestation reduces both dry and wet season flow. While the absolute flow reduction is largest during the wet season, the dry season experiences a larger proportional reduction, which may have important consequences for downstream water supply.

\subsection{Water supply in the Andes}

The páramo is the major water source for the Andean highlands. Groundwater extraction in the Andean highlands is complicated and expensive due to the complex geology. Therefore surface water is intensively used. For instance, more than $98 \%$ of the water used for irrigation in Ecuador is supplied by surface water resources (FAO, 2000). In the highlands, this surface water is mainly provided by the páramo, because of the lack of human activities and associated pollution, and the constancy of its water supply. Large cities such as Bogotá and Quito rely almost entirely on surface water from the páramo. Streams from the páramo are locally known for their large and sustained base flow (Buytaert et al., 2006c). The constant flow is used to bridge dry periods in the lower Andean areas. It allows for small and efficient water capture installations without the need for large buffering reservoirs. Despite the socio-economic importance of both the quantity and the shape of the hydrographs of rivers descending from the páramo, the impact of pine plantations on the hydrological regime of the páramo has received very little attention. Given the specific climatic and geographical setting of the páramo ecosystem, its hydrological characteristics may differ significantly from that of other ecosystems.

A major reason for this lack of attention is the paucity of hydrological and meteorological time series from the páramo. Historically, monitoring efforts have been focused on the more densely populated interandean valley. Monitoring is also complicated because of the remoteness, difficult access and the harsh climate of the páramo. Long-term data series also suffer from a lack of sufficient temporal resolution and from quality problems and datagaps due to failing of instruments and inappropriate maintenance (Célleri et al., 2006; Buytaert et al., 2006c). Additionally, most hydrological stations are located further downstream and cover large catchments of which only a small part is páramo. Land use changes in these catchments are poorly documented and very diverse, making them less suitable for land cover change analysis. As a result, no data exist from adequately designed paired catchment experiments, in which two catchments with similar control characteristics in terms of soils, topography and vegetation are monitored both before and after conversion of one catchment to a new land use type.

\subsection{Aim of the study}

In this study, the water balance and flow duration curves of páramo catchments with different land uses are compared to assess the impact of afforestation and cultivation on evapotranspiration and on the hydrological regime of rivers from the páramo. To reduce the problem of the lack of calibration period, catchment selection and monitoring designs were done as follows. Small headwater catchments were monitored with homogeneous properties in terms of land use, soil properties, geology and climate. A high temporal resolution of discharge monitoring (15-min intervals) accounts for the fast response of these catchments. A major advantage of the catchments is the occurrence of virtually impermeable bedrock and the lack of a groundwater storage system. This greatly reduces interference of deep infiltration and groundwater storage in the calculation of the water balance. Furthermore, the páramos in the rio Paute basin are perennially wet, and seasonal variability of the climate is low. Autocorrelation in daily rainfall series has a lag time of only 3 days (Buytaert et al., 2006). As a result, the changes in soil moisture storage over time are relatively small in these catchments. Former research in the study area has indicated 
that erratic and short dry-wet cycles determine the temporal soil moisture variability, while seasonal variability is very low (Buytaert et al., 2005a). Additionally, due the lack of climatic seasonality, evapotranspiration is relatively constant throughout the year. It is therefore likely that the storage variations are averaged out faster than in the case of a clear seasonal trend, and that reliable estimates of evapotranspiration are possible over a relatively short period.

\section{Study area}

\subsection{The páramo ecosystem}

The páramo is a mountainous wetland ecosystem covering the upper Andes region of Venezuela, Colombia, Ecuador and northern Peru. The ecosystem extends between the continuous natural forest border (about $3500 \mathrm{~m}$ altitude) and the permanent snow (about $5000 \mathrm{~m}$ ). It consists of accidented, mostly glacier formed valleys and plains with a large variety of lakes, peat bogs and wet grasslands intermingled with shrublands and lowstatured forest patches (Luteyn et al., 1992; Castano, 2002; Hofstede et al., 2003). Its vegetation consists mainly of tussock grasses, ground rosettes, dwarf shrubs cushion plants and conspicuous giant rosettes such as Espeletia and Puya (Hofstede, 1995; Hedberg, 1992; Vargas and Zuluaga, 1986).

The páramo features a typical high tropical mountain climate. Due to its location close to the equator, the daily solar radiation is almost constant throughout the year, and seasonal climate variation is low. The páramo of the Paute river basin is perennially wet. Mean air temperature is constant throughout the year (about $8^{\circ} \mathrm{C}$ at $3600 \mathrm{~m}$ ), but day-night cycles are marked, with temperatures close to freezing at night and reaching $20^{\circ} \mathrm{C}$ during the day. Due to the expressed diurnal cycle, no snow accumulation takes place. Rainfall is characterised by frequent, low volume events (drizzle), ranges between 1000 and $1500 \mathrm{~mm} \mathrm{year}^{-1}$ and has a low seasonal variability.

The soils are volcanic in origin and are classified as Andisols, Entisols, Inceptisols and Histosols. They form a uniform blanket covering the tertiary bedrock of the Andean cordilleras. Depending on the location, soil thickness ranges from a few centimeters to more than $1 \mathrm{~m}$. The cold and wet climate, and the low atmospheric pressure favour organic matter accumulation in the soil. As a result, the soils are dark and humic and have excellent water infiltration and retention capacities. Soil organic C may be as high as $30 \%$, both in saturated valley bottoms and on slopes, and water storage capacities of more than $0.4 \mathrm{~cm}^{3} \mathrm{~cm}^{-3}$ are not uncommon (Buytaert et al., 2005a). Very few data are available for the calculation of a reference evapotranspiration in this ecosystem. Additionally, it is not certain whether the calculation methods are valid due to the extreme climatic conditions. Based on meteorological data from a meteorological station installed at the Chanlud damsite in the Machangara valley (Fig. 1), an average ET0 of $1.77 \mathrm{~mm} \mathrm{day}^{-1}$ or $646 \mathrm{~mm} \mathrm{year}^{-1}$ is obtained using the Penman-Monteith method.

\subsection{Experimental catchments}

The four study catchments are located in the páramo of the rio Paute basin, south Ecuador (Fig. 1). To minimise climate variability, the experimental catchments were chosen at a similar altitude, and in the same mountain range (Table 1). Two catchments, MR1 and MP1 are located next to each other in the Tomebamba valley near Marianza, west of Cuenca. Two other catchments, HR1 and SC1 are located in the Machangara valley NW of Cuenca at locations known as Huagrahuma and Soroche. The distance between HR1 and SC1 is about $5 \mathrm{~km}$. HR1 and $\mathrm{SC} 1$ are about $20 \mathrm{~km}$ from MR1 and MP1. The geology of all
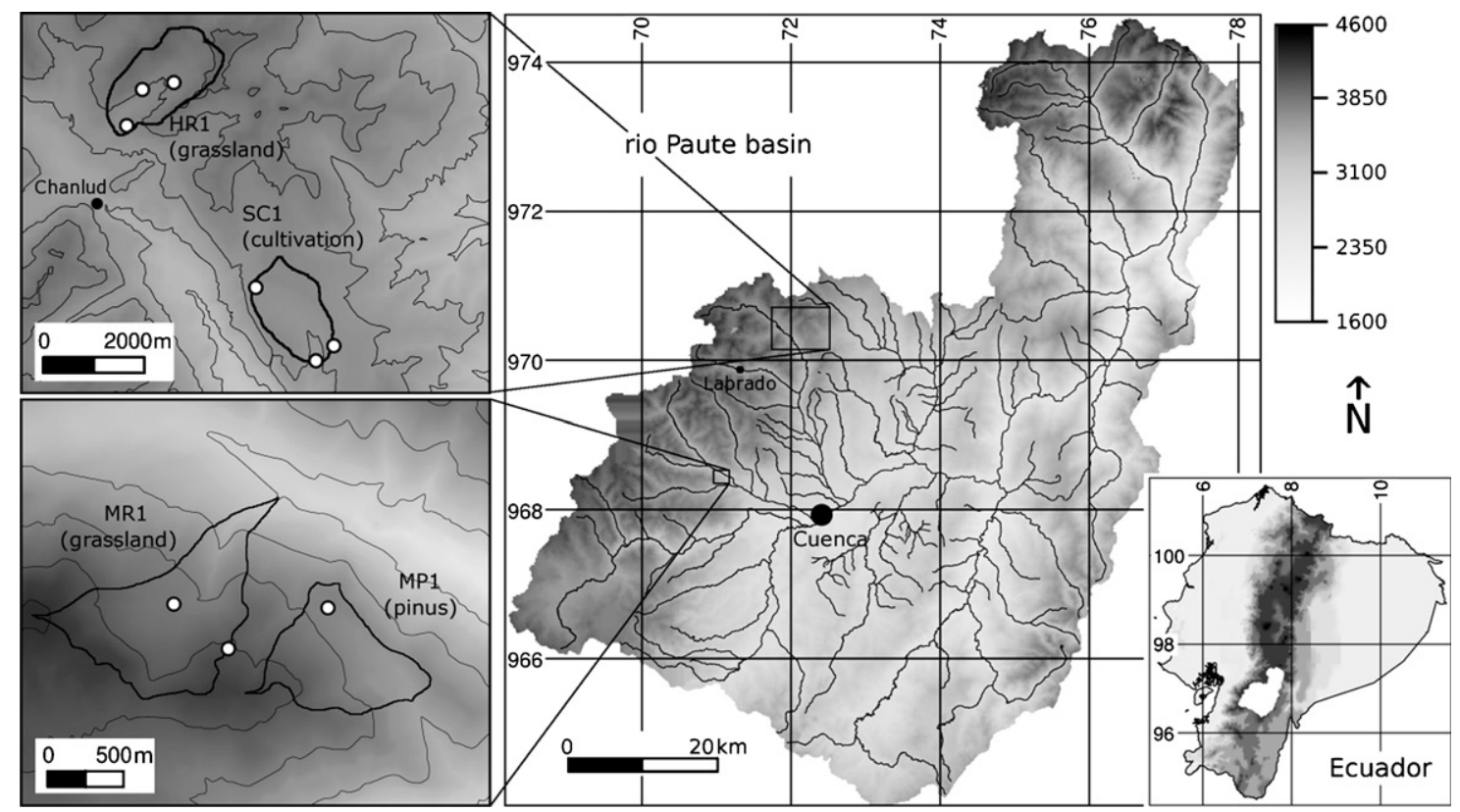

Fig. 1. Map of the study region indicating the experimental catchments. (o) Location of the rain gauges used in the study. 
Table 1

Major properties and water balance of the experimental catchments

\begin{tabular}{|c|c|c|c|c|c|c|c|c|c|c|}
\hline Name & Location & Altitude (m) & $\begin{array}{l}\text { Avg. } \\
\text { alt. (m) }\end{array}$ & $\begin{array}{l}\text { Area } \\
\left(\mathrm{km}^{2}\right)\end{array}$ & Monitoring period & $\begin{array}{l}\text { Rain } \\
\left(\mathrm{mm} \mathrm{year}^{-1}\right)\end{array}$ & $\begin{array}{l}\text { Discharge } \\
\left(\mathrm{mm} \mathrm{year}^{-1}\right)\end{array}$ & $\begin{array}{l}\text { ET } \\
\left(\mathrm{mm} \mathrm{year}^{-1}\right)\end{array}$ & $\mathrm{RC}$ & Land use \\
\hline MR1 & Marianza & $2980-3810$ & 3496 & 0.84 & 29/05/04-29/08/05 & 1028 & 506 & 522 & 0.53 & Grassland \\
\hline MP1 & Marianza & $3230-3710$ & 3414 & 0.63 & 29/05/04-29/08/05 & 939 & 175 & 764 & 0.19 & Pine \\
\hline HR1 & Huagrahuma & $3690-4100$ & 3894 & 2.58 & $04 / 09 / 01-17 / 06 / 05^{\mathrm{a}}$ & 1286 & 933 & 353 & 0.73 & Grassland \\
\hline $\mathrm{SC} 1$ & Soroche & $3520-3720$ & 3650 & 1.59 & $29 / 10 / 01-29 / 09 / 03^{b}$ & 1041 & 646 & 395 & 0.62 & Cultivation \\
\hline
\end{tabular}

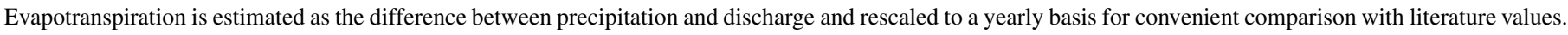
ET, evapotranspiration; Avg. alt., average altitude; RC, runoff coefficient.

${ }^{a}$ With a gap between $07 / 02 / 2003$ and 13/08/2003 .

b With a gap between $21 / 02 / 2002$ and 11/05/2002.

catchments consists of Cretaceous and early Tertiary lavas and andesitic volcanoclastic deposits shaped and compacted by glacier activity during the last ice age (Coltorti and Ollier, 2000; Hungerbühler et al., 2002). The hydraulic conductivity of the bedrock is low, particularly compared to the hydraulic conductivity of the thin layer of volcanic ashes that constitute the soil layer (Buytaert et al., 2005a). On average, the soil layer is about $80 \mathrm{~cm}$ thick, with bedrock outcroppings at convex locations and hilltops (Buytaert et al., 2006c). Due to the steep topography, no permanent water table exists, except in local depressions where flows accumulate and permanent saturation occurs. As a result, no groundwater is present, and water flow is restricted to overland flow and subsurface flow in the soil layer above the bedrock. General characteristics of the studied catchments are given in Table 1.

MR1 and HR1 are the reference sites, covered with typical páramo vegetation, which consists of tall grasses and low shrubs (Fig. 2). In the lower area of MR1, low-statured cloud forest is also present, estimated at about $20 \%$ of the catchment area. In MR1 and MP1, human interference is restricted to extensive grazing by free roaming animals. As such, they are representative for the "natural" páramo in the region, because very few locations exist where the traditional grazing practices do not occur.

Catchment MP1 is planted with P. patula. Foresters in the area generally choose this species over $P$. radiata because of its

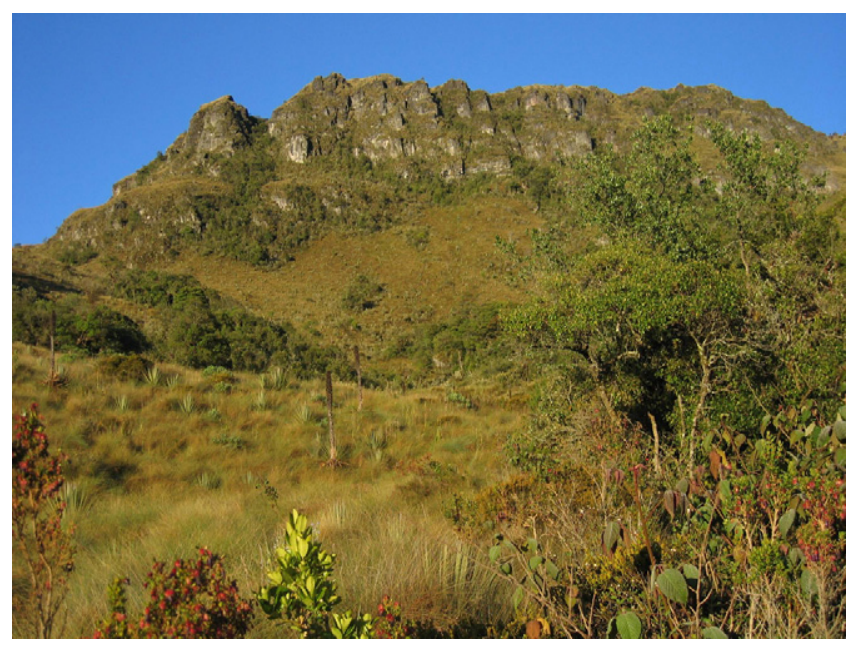

Fig. 2. Picture of the natural páramo vegetation in MR1, consisting of tussock grasses intermingled with small shrubs. resistance to Dothistroma pini. In the past, infections with Dothistroma have had devastating effects on $P$. radiata plantations (Hofstede et al., 1998). The forest has an age of about 20 years, a tree density of about $1000 \mathrm{stems} \mathrm{ha}^{-1}$, and occupies more than $90 \%$ of the catchment.

In catchment $\mathrm{SC} 1$, intensive grazing, artificial drainage and cultivation of potatoes take place. Cultivation occurs through the entire year, without a specific growing cycle and occupies about $10 \%$ of the catchment. In the rest of the catchment, the original grass vegetation has been replaced by more nutritious species that are intensively grazed. The intensively grazed area expanded considerably during the monitoring period, from $30 \%$ to more than $50 \%$ of the catchment. The cultivated and grazed areas are artificially drained, with an average drain space of 10-15 m. Drainage was expanded to the natural vegetation during the monitoring period.

\section{Monitoring}

Streamflow was measured at the outlet of each catchment using a concrete $\mathrm{V}$-shaped weir and a pressure transducer (Global Water WL16) in the upstream reservoir. Water level recordings were made at $15 \mathrm{~min}$ intervals. The KindsvaterShen relation (US Bureau of Reclamation, 2001) was used to convert the water level to discharge. Three tipping bucket rain gauges (Davis Rain Collector II) were installed in catchments larger than $1 \mathrm{~km}^{2}$ (HR1 and SC1), while the smaller catchments MR1 and MP1 were equipped with two rain gauges. The resolution of the rain gauges is 0.20 or $0.254 \mathrm{~mm}$ and they were installed at a height of $1.20 \mathrm{~m}$. Due to malfunctioning of a rain gauge in MP1, only one rain gauge could be used for most of the monitoring period in this catchment. Long-time monthly rainfall is available from a manual rain gauge at Labrado (Fig. 1).

The catchments in Marianza (MR1 and MP1) were monitored over the same time period, from 29/05/2004 to 22/08/2005. HR1 and SC1 are monitored over a different period, respectively 04/09/2001 to 17/06/2005 and 29/10/2001 to $29 / 09 / 2003$ (Table 1). Although seasonal climate variations in the páramo are low, care should be taken when comparing the catchments from Marianza with HR1 and SC1, and the data from the latter catchments are primarily given for indicative purposes. ET0 could not be calculated due to a lack of meteorological data for the monitored period. 


\section{Methods}

The discharge data were normalised using the total area of each catchment, which was determined using a downhill flow algorithm on a $25 \mathrm{~m}$ resolution digital elevation model (DEM) and corrected with field observations. The DEM was generated from digitised elevation contours with an interval of $20 \mathrm{~m}$ and a scale of 1:25,000, using regularised spline with tension (Mitasova and Mitas, 1993). The tipping bucket rainfall data were converted to the matching discharge timesteps. Precipitation was averaged over each catchment using a weighted average based on Thiessen polygons.

Daily and monthly data were calculated by taking the sum of the $15 \mathrm{~min}$ data over the respective time periods. Average daily data were rescaled to a yearly basis for a more convenient comparison with literature values.

Maximum intensity-duration curves of the precipitation were obtained by a moving window approach on the original tipping bucket data. Finally, flow duration curves were calculated based on the daily flows.

\section{Results and discussion}

\subsection{The hydrological regime}

Fig. 3 shows a representative section of the measured rainfall and discharge of MR1 and MP1 at a resolution of $15 \mathrm{~min}$. The rainfall time series show that most rainfall events are of low intensity. Over the monitoring period, a maximum intensity of $39.6 \mathrm{~mm} \mathrm{~h}^{-1}$ was observed for a 15 -min interval, decreasing to $15.7 \mathrm{~mm} \mathrm{~h}^{-1}$ for a 1-h interval (Fig. 4). Average intensities are much lower though (Fig. 3), and generally below the saturated hydraulic conductivity of the soils. Buytaert et al. (2005a) observed an average saturated hydraulic conductivity in the HR 1 catchment between 10 and $20 \mathrm{~mm} \mathrm{~h}^{-1}$ (depending on the used method), with maximum values up to $70 \mathrm{~mm} \mathrm{~h}^{-1}$. Therefore, infiltration excess overland flow is virtually nonexisting (Poyck, 2006). Additionally, the extremely high water storage capacity of the soils limits saturation excess overland

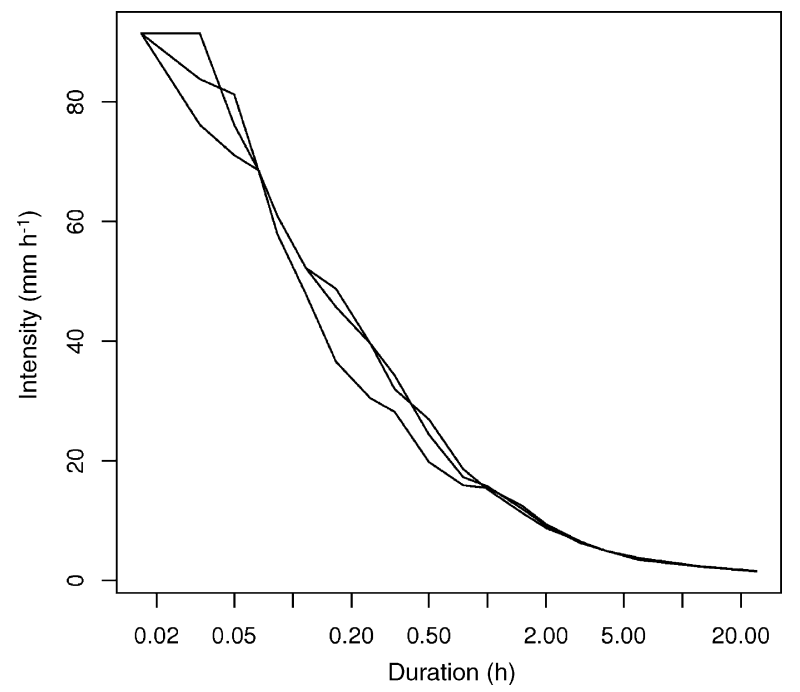

Fig. 4. Maximum intensity-duration curves over the monitored period for the rain gauges at Marianza (MR1 and MP1 catchments).

flow. Indeed, most rainfall events do not generate significant peak flows. Peaks only occur after several days of rainfall, such as on 11/09/2004 as observed in Fig. 3. Thus, the hydrological regime of the natural catchment is dominated by a slow base flow response. This constant river flow and the relative absence of high peaks is also clearly reflected in the flat profile of the flow duration curves of the natural catchments (Fig. 5). The small but sharp peak in the peakflow section of the curves represents the occasions where saturated overland flows occur.

Flow duration curves are compared in pairs to assess the impact of afforestation and cultivation (Fig. 5). The impact of pine plantations is shown in Fig. 5a. The flow regime changes drastically, and both peak and base flows are severely reduced. The lowest flow rates approach zero $\left(0.016 \mathrm{~mm} \mathrm{day}^{-1}\right)$, clearly reflecting the higher water consumption of P. patula in this environment. The similar reduction in low and high flows is typical for many catchments described in literature that have a moderate to high rainfall regime. This is in contrast with areas with an annual precipitation is lower than potential

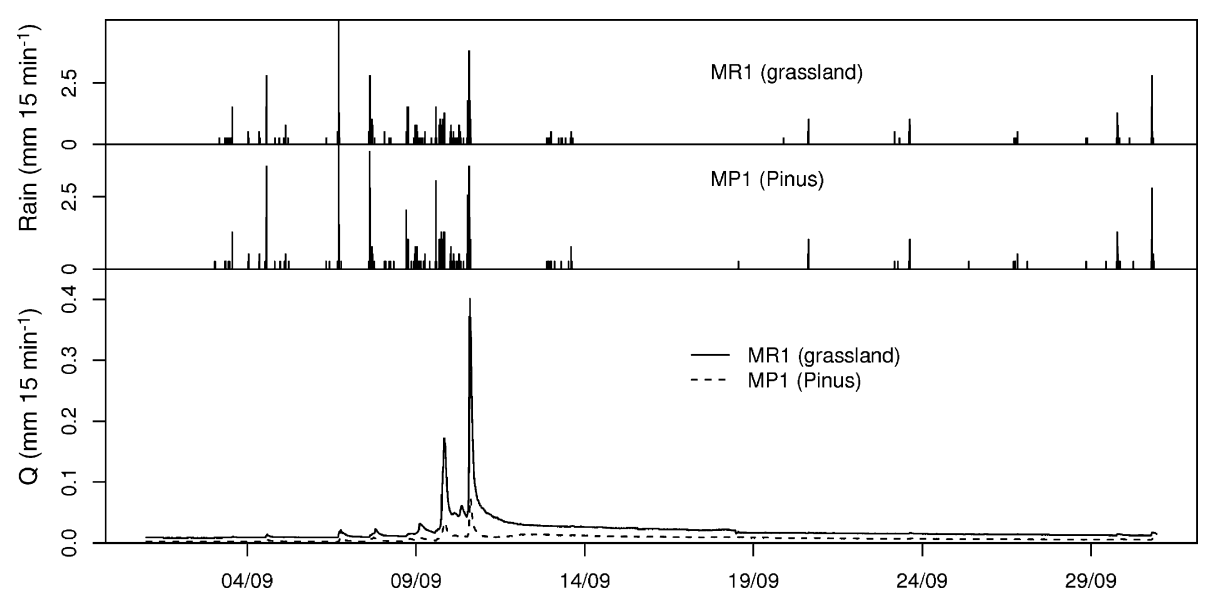

Fig. 3. Representative sample of the discharge of MR1 and MP1. Note that the rainfall event with the highest intensity on 07/09/04 did not generate any representative discharge, illustrating the lack of infiltration excess overland flow. 

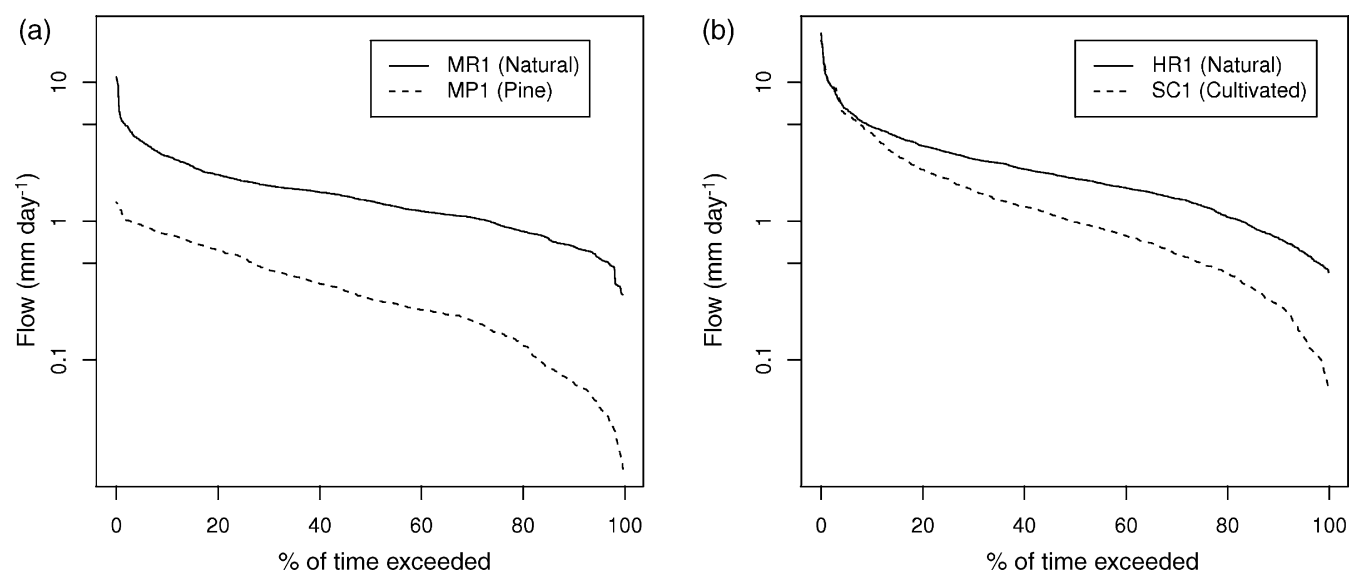

Fig. 5. Flow duration curves for the studied periods (Table 1), based on daily discharges. (a) Impact of afforestation and (b) impact of cultivation.

evapotranspiration, where complete cessation of flows is common (e.g., Scott and Lesch, 1997; Brown et al., 2005).

The impact of cultivation on the flow duration curves is less drastic. High flows are similar, but low flows reduce markedly, resulting in a steeper curve (Fig. 5b). A slightly lower curve would be expected based on the fact that over the monitored period, rainfall was about $20 \%$ lower in the cultivated SC1 catchment than in HR1. Nevertheless, the steeper slope of the curve of the cultivated catchment indicates a shift from base flow to peak flows. This would mean a loss of water regulation capacity of the cultivated catchment and is consistent with former studies (Buytaert et al., 2004). It is attributed to a higher hydraulic conductivity of cultivated soils and particularly the introduction of artificial drains, as both mechanisms enhance soil drainage.

\subsection{Water yield}

The cumulative water balance over time of catchments MR1 and MP1 is given in Fig. 6. Datagaps prevent the construction of such a curve in HR and SC1. The cumulative rainfall curve shows a high linearity, illustrating the lack of seasonality. Although monthly rainfall can be highly variable (Fig. 7), it is also highly random. Dry and wet periods alternate with a high frequency and rarely span more than a month. As a result, fluctuations in the internal catchment storage are small and only significant over a short time in the order of months rather than years. This is clearly reflected in the linearity of the cumulative curve representing the difference between rainfall and discharge in Fig. 6 and suggests that the error on the evapotranspiration, which is calculated as the difference between rainfall and discharge, is also small. Additionally, measurement errors are minimised by the use of a short measuring interval for discharge and a high density of rain gauges.

The average rainfall, discharge and evapotranspiration over the monitoring period is rescaled to a yearly basis and given in Table 1 for all studied catchments. Again, the existence of datagaps in HR1 and SC1 increase the uncertainty on these data. Comparing the natural páramo catchments, the discharge of MR1 (506 mm year ${ }^{-1}$ ) is considerably lower than HR1 $\left(933 \mathrm{~mm}\right.$ year $\left.^{-1}\right)$. Even when the difference in precipitation is taken into account, evapotranspiration is $169 \mathrm{~mm} \mathrm{year}^{-1}$ higher in MR1, which can be attributed to several processes. The difference in average altitude of both catchments is about $400 \mathrm{~m}$ (Table 1). The local lapse rate is $0.55{ }^{\circ} \mathrm{C}$
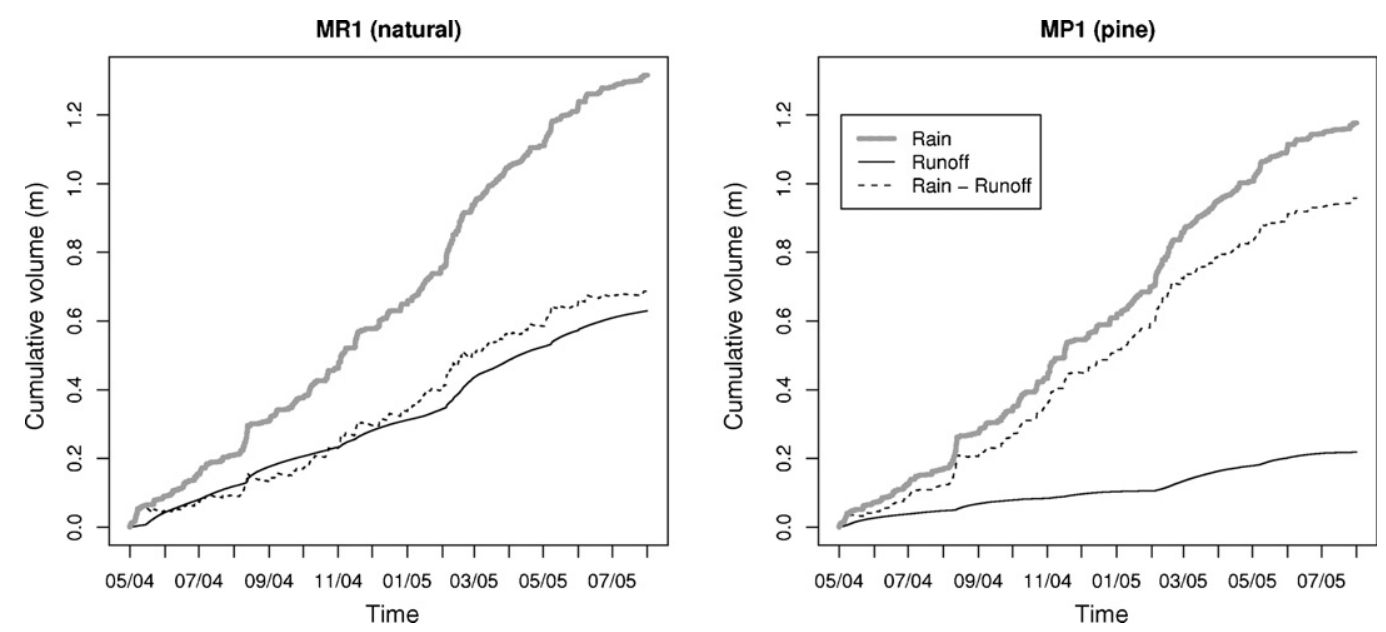

Fig. 6. Cumulative water balance of the catchments MR1 and MP1. The strong linearity of the curves are indicative for the lack of seasonality in the páramo climate and thus a small impact of internal catchment storage on the water balance over time. 


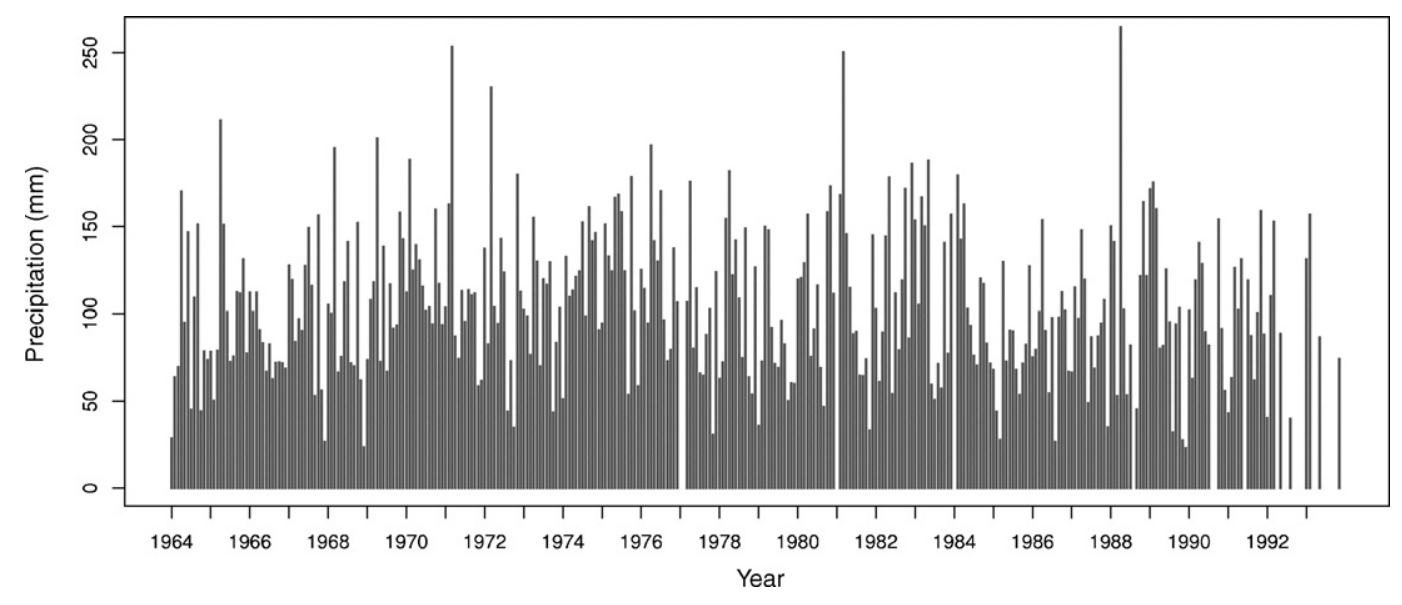

Fig. 7. Long-term monthly rainfall registered at the páramo of Labrado, about $10 \mathrm{~km} \mathrm{SW} \mathrm{of} \mathrm{HR1} \mathrm{and} \mathrm{SC1.}$

$100 \mathrm{~m}^{-1}$ (Bacuilima et al., 1999), giving rise to a temperature difference of about $2{ }^{\circ} \mathrm{C}$ and thus a difference in evapotranspiration. Additionally, the lower rainfall regime in Marianza results in a lower cloudiness which also enhances evapotranspiration. Finally, the low rain intensities enhance interception, and whether intercepted humidity evaporates is also strongly dependent on the temperature and cloudiness. The occurrence of natural cloud forest in the lower part of MR1 is unlikely to make a large difference, as the annual catchment evapotranspiration of $352 \mathrm{~mm}$ agrees very well with the range of 310 $390 \mathrm{~mm}$ reported by Bruijnzeel (2005) for upper montane cloud forest with high fog interception.

The average discharge of the cultivated catchment (SC1) is $646 \mathrm{~mm}$ year $^{-1}$, which is in between the values of both natural catchments. The average altitude and the average precipitation are in between those of the natural catchments as well, so it is difficult to attribute a prominent role to the vegetation in the observed differences.

On the other hand, the difference in water yield between the natural catchments and the afforested catchment is considerably higher. Over the total monitoring period, the water yield of the afforested catchment MP1 is $219 \mathrm{~mm}$, which is $175 \mathrm{~mm}$ year $^{-1}$ and only a third of the neighbouring natural catchment (506 mm year ${ }^{-1}$ ). A part of the difference can be attributed to the lower rainfall in MP1 (a difference of $89 \mathrm{~mm} \mathrm{year}^{-1}$ ). The remaining $242 \mathrm{~mm} \mathrm{year}^{-1}$ must be caused by evapotranspiration, variation in internal storage and errors in the measurements. As discussed before, the storage variation and measurement errors are probably small, and the observed difference is thus a fairly good estimate for the impact of $P$. patula on the evapotranspiration in the páramo ecosystem. This is strenghtened by the fact that the observed values are comparable to differences in evapotranspiration between grassland and pine reported in literature.

For instance, Zhang et al. (2001) and Brown et al. (2005) summarised results from afforestation experiments and mathematical relations. The so-called Zhang curves relate land cover, average annual rainfall and mean annual evapotranspiration. These curves return an average difference in evapotranspiration of about $300 \mathrm{~mm}$ for an annual mean rainfall of $1100 \mathrm{~mm}$. Farley et al. (2005) summarize the 26 case studies of afforestation, 13 of which were originally grassland. A plantation age of 26-30 years coincides with the maximum observed decrease, quantified at $456 \pm 48 \mathrm{~mm}$. However, this study included both pine and eucalyptus plantations and the latter generally have a stronger impact.

For specific case studies of $P$. patula, one of the most comparable situations is the South African Cathedral Peak study described by, e.g., Schulze et al. (1978) and Schulze and George (1987). These catchments are located at an altitude ranging from 1844 to $2454 \mathrm{~m}$ and experience an annual precipitation of $1400 \mathrm{~mm}$. The soils are basalt-derived silty clays with an average depth of $0.8 \mathrm{~m}$. The original vegetation consisted of Themada grassland, of which $75 \%$ was replaced by $P$. patula. An average reduction of $257 \mathrm{~mm}_{\text {year }}^{-1}$ was reported, with a maximum reduction of $440 \mathrm{~mm} \mathrm{year}^{-1}$ occurring at 22 years and a slight recuperation afterwards (Bosch and Hewlett, 1982). In a similar experiment, the South African Mokobulaan catchment was forested with $P$. patula (Lill et al., 1980; Scott and Lesch, 1997). This catchment dried up completely after 12 years, and peak reductions of 205 and $257 \mathrm{~mm}$ year $^{-1}$ were estimated based on comparison with a control catchment.

Studies on $P$. radiata also report comparable results. For example, in the Glendhu catchment in New Zealand (Rowe, 2003), having an annual precipitation of $1340 \mathrm{~mm}$ year $^{-1}, 75 \%$ of a tussock grassland was planted with $P$. radiata. After canopy closure in 1991 an average reduction of $235 \mathrm{~mm} \mathrm{year}^{-1}$. Catchments where pasture is afforested with $P$. radiata give an average reduction of $230 \mathrm{~mm}$ year ${ }^{-1}$ (Purukohukohu catchment (Rowe, 2003)) and $170 \mathrm{~mm} \mathrm{year}^{-1}$ (Moutere C14 (Smith, 1992)). For a complete overview see Adams and Fowler (2006).

\subsection{Socio-economic implications}

The 50\% decrease in water yield from the afforested catchment poses important questions about the water supply of the páramo. The studied catchments MR1 and MP1 are part of the Tomebamba watershed, which is a major water supply area for the city of Cuenca (about half a million inhabitants). A 
decrease in water supply, and specifically a decrease in base flow due to afforestation may put the water supply at risk. Current buffer reservoirs are not designed to bridge large periods of low flows which may increase in frequency in case of large scale afforestation. A similar problem arises for Ecuador's largest hydropower plant, located on the Paute river about $75 \mathrm{~km}$ downstream of Cuenca. Local experts estimate that the power plant depends completely on páramo water during dry periods. Large scale afforestation and thus a decrease of base flow from the páramo may pose problems of water supply during these periods. Data about the scale of afforestation are scarce as currently many efforts are local. However, the fact that afforestation is often supported by local governments and agencies stresses the importance of an adequate management of the páramo region.

A second concern is the possible irreversibility of the water regulation loss. The high infiltration and water storage capacity of the páramo soils are closely related to their exceptionally high organic $\mathrm{C}$ content. As in many Andosols, soil organic $\mathrm{C}$ is stabilised by organometallic complexation with non-crystalline minerals released from volcanic ashes (Wada, 1985; Nanzyo et al., 1993; Buytaert et al., 2005b). Afforestation reduces soil organic matter contents because of a faster decomposition due to the lower soil water content, and because of lower production in the soil. Grasses tend to form extensive fine root systems which contribute significantly to the organic matter accumulation in the soils (Hofstede and Rossenaar, 1995), while root production and turnover of pine and other conifers tends to be lower (Guo and Gifford, 2002). As a result, subsequent leaching of the non-crystalline minerals may hamper the restoration of the original organic $\mathrm{C}$ content after deforestation. However, to our knowledge, no studies exist about the long-term effect of pine forests on the soil properties and their hydrological behaviour in the páramo ecosystem.

\section{Conclusions}

Many studies have investigated the impact of afforestation on water yield at the catchment scale but none of them so far has covered the tropical Andes region. This contrasts with the intense afforestation efforts in this area, in particular in the tropical alpine páramo grasslands. The flow duration curves have a flat profile and express the good water regulation capacity of the páramo ecosystem. Discharge is dominated by base flow. Comparing rainfall intensities and existing infiltration data indicates that infiltration excess overland flow is nearly absent.

Analysing the long term monthly rainfall in the study region shows that strong variations in catchment water storage may occur at this time scale, but these variations are erratic and show little seasonal trends. This observation suggests that the impact of changes in water storage variations on the water balance at larger time periods is small. This is confirmed by the cumulative water balance, which is highly linear over time.

Over the entire monitoring period (about 15 months), the observed differences in water yield between an afforested and a grassland catchment are $242 \mathrm{~mm}$ year ${ }^{-1}$ or about $50 \%$. These values are in line with data reported in literature although they are mainly from South Africa, Australia and New Zealand. This fact increases the credibility of the results for extrapolation towards ungauged basins. It opens perspectives for better water management and may avoid future water scarcity in regions that rely heavily on surface water for their water supply. Nevertheless, in the case of the south Ecuadorian páramo, afforestation planning should be done with care, given the fragility of the soils and the socio-economic importance of surface water from the páramo.

\section{Acknowledgements}

The authors thank Dr. Felipe Cisneros, Director of the Soil and Water Management Programme of the Universidad de Cuenca, for logistic help during the field study. The fieldwork was funded by an Universidad de Cuenca DIUC grant. During the fieldwork, Buytaert was funded by a K.U. Leuven postdoctoral grant (PDM). We also thank the two anonymous reviewers for their useful comments to improve the paper.

\section{References}

Adams, K.N., Fowler, A.M., 2006. Improving empirical relationships for predicting the effect of vegetation change on annual water yield. J. Hydrol. 90-115.

Bacuilima, F.L., Bacuilima, J.C., Bermeo, W.A., 1999. Caracterización de clima por microcuencas en el Austro Ecuatoriano. Master's Thesis. Universidad de Cuenca, Facultad de Ingenieria, Cuenca.

Bosch, J.M., Hewlett, J.D., 1982. A review of catchment experiments to determine the effect of vegetation changes on water yield and evapotranspiration. J. Hydrol. 55, 3-23.

Brown, A.E., Zhang, L., McMahon, T.A., Western, A.W., Vertessy, R.A., 2005. A review of paired catchment studies for determining changes in water yield resulting from alterations in vegetation. J. Hydrol. 310, 28-61.

Bruijnzeel, L.A., 2004. Hydrological functions of tropical forests: not seeing the soil for the trees? Agric. Ecosyst. Environ. 104, 185-228.

Bruijnzeel, L.A., 2005. Tropical montane cloud forest: a unique hydrological case. In: Bonell, M., Bruijnzeel, L.A. (Eds.), Forests, Water and People in the Humid Tropics, Cambridge University Press, Cambridge, pp. 462-484.

Buytaert, W., Célleri, R., De Bièvre, B., Hofstede, R., Cisneros, F., Wyseure, G., Deckers, 2006c. J. Human impact on the hydrology of the Andean páramos. Earth Sci. Rev. 79, 53-72.

Buytaert, W., Célleri, R., Willems, P., De Bièvre, B., Wyseure, G., 2006 a. Spatial and temporal rainfall variability in mountainous areas: A case study from the south Ecuadorian Andes. J. Hydrol. 329, 413-421.

Buytaert, W., De Bièvre, B., Wyseure, G., Deckers, J., 2004. The use of the linear reservoir concept to quantify the impact of land use changes on the hydrology of catchments in the Ecuadorian Andes. Hydrol. Earth Syst. Sci. $8,108-114$.

Buytaert, W., De Bièvre, B., Wyseure, G., Deckers, J., 2005a. The effect of land use changes on the hydrological behaviour of Histic Andosols in south Ecuador. Hydrol. Process. 19, 3985-3997.

Buytaert, W., Deckers, J., Wyseure, G., 2006b. Description and classification of highly weathered Andosols in the south Ecuadorian páramo. Geomorphology 73, 207-221.

Buytaert, W., Sevink, J., Leeuw, B.D., Deckers, J., 2005b. Clay mineralogy of the soils in the south Ecuadorian páramo region. Geoderma 127, 114 129.

Castano, C., 2002. Páramos y ecosistemas alto andinos de Colombia en condición hotspot y global climatic tensor. IDEAM, Bogotá, pp. 387.

Célleri, R., Willems, P., Buytaert, W., Feyen, J., 2006. Space-time variability of rainfall in the Paute River basin of South Ecuador. Hydrol. Process., in press. 
Chapela, I.H., Osher, L.J., Horton, T.R., Henn, M.R., 2001. Ectomycorrhizal fungi introduced with exotic pine plantations induce soilcarbon depletion. Soil Biol. Biochem. 33, 1733-1740.

Colmet-Daage, F., Cucalon, F., Delaune, M., Gautheyrou, J., Gautheyrou, M., Moreau, B., 1967. Caractéristiques de quelques sols d'Equateur dérivés de cendres volcaniques. I. Essai de caractérisation des sols des régions tropicales humides. Cahiers ORSTOM, série Pédologie 5, 1-38.

Coltorti, M., Ollier, C.D., 2000. Geomorphic and tectonic evolution of the Ecuadorian Andes. Geomorphology 32, 1-19.

FAO, 2000. Irrigation in Latin America and the Caribbean in Figures. Water Report 20. FAO, 365 pp.

Farley, K.A., Jobbágy, E.G., Jackson, R.B., 2005. Effects of afforestation on water yield: a global synthesis with implications for policy. Global Change Biol. 11, 1565-1576.

Farley, K.A., Kelly, E.F., 2004. Effects of afforestation of a páramo grassland on soil nutrient status. Forest Ecol. Manage. 195, 271-290.

Farley, K.A., Kelly, E.F., Hofstede, R.G.M., 2004. Soil organic carbon and water retention after conversion of grasslands to Pine plantations in the Ecuadorian Andes. Ecosystems 7, 729-739.

Guo, L.B., Gifford, R.M., 2002. Soil carbon stocks and land use change: a meta analysis. Global Change Biol. 8, 345-360.

Hedberg, O., 1992. Afroalpine vegetation compared to páramo: convergent adaptations and divergent differentiation. In: Balslev, H., Luteyn, J.L. (Eds.), Páramo: An Andean Ecosystem under Human Influence. Academic Press, London, pp. 15-30.

Hofstede, R., Segarra, P., Mena, P.V., 2003. Los Páramos del Mundo. Global Peatland Initiative/NC-IUCN/EcoCiencia, Quito, p. 299.

Hofstede, R.G.M., 1995. Vegetative structure, microclimate, and leaf growth of a páramo tussock grass species, in undisturbed, burned and grazed conditions. Vegetatio 119, 53-65.

Hofstede, R.G.M., Groenendijk, J.P., Coppus, R., Fehse, J.C., Sevink, J., 2002. Impact of pine plantations on soils and vegetation in the Ecuadorian High Andes. Mountain Res. Dev. 22, 159-167.

Hofstede, R.G.M., Lips, J., Jongsma, W., Sevink, Y., 1998. Geografía ecología y forestación en la sierra alta del Ecuador. Ediciones Abya Yala, Quito, Ecuador.

Hofstede, R.G.M., Rossenaar, A.J.G.A., 1995. Biomass of grazed, burned and undistributed páramo grasslands Colombia. 2. Root mass and aboveground/ belowground ratio. Arctic Alpine Res. 27, 13-18.

Hungerbühler, D., Steinmann, M., Winkler, W., Seward, D., Eguez, A., Peterson, D.E., Helg, U., Hammer, C., 2002. Neogene stratigraphy and Andean geodynamics of southern Ecuador. Earth Sci. Rev. 57, 75-124.

Le Maitre, D.C., Scott, D.F., Colvin, C., 1999. A review of information on interactions between vegetation and groundwater. Water SA 25, 137-152.

Lill, W.S.V., Kruger, F.J., Wyk, D.B.V., 1980. The effect of afforestation with Eucalyptus grandis Hill Ex Maiden and Pinus patula Schlecht. et Cham. on streamflow from experimental catchments at Mokobulaan, Transvaal. J. Hydrol. 107-118.

Luteyn, J.L., 1992. Páramos: why study them? In: Balslev, H., Luteyn, J.L. (Eds.), Páramo: An Andean Ecosystem under Human Influence. Academic Press, London, pp. 1-14.

Luteyn, J.L., Cleef, A.M., Rangel, O., 1992. Plant diversity in páramo: towards a checklist of páramoplants and generic flora. In: Balslev, H., Luteyn, J.L. (Eds.), Páramo: An Andean Ecosystem under Human Influence. Academic Press, London, pp. 71-84.

Mitasova, H., Mitas, L., 1993. Interpolation by regularized spline with tension: I. Theory and implementation. Math. Geol. 25, 641-655.

Nanzyo, M., Shoji, S., Dahlgren, R., 1993. Volcanic ash soils: genesis, properties and utilisation. In: Developments in Soil Science No. 21, Elsevier, Amsterdam, p. 288.

Poulenard, J., Bartoli, F., Burtin, G., 2002. Shrinkage and drainage in aggregates of volcanic soils: a new approach combining mercury porosimetry and vacuum drying kinetics. Eur. J. Soil Sci. 53, 563-574.

Poulenard, J., Podwojewski, P., Herbillon, A.J., 2003. Characteristics of nonallophanic Andisols with hydric properties from the Ecuadorian páramos. Geoderma 117, 267-281.

Poyck, S., 2006. Closing the water balance for a hillslope plot in the páramo. Master's Thesis. Wageningen University.

Roberts, G., Harding, R.J., 1996. The use of simple process-based models in the estimate of water balances for mixed land use catchments in East Africa. J. Hydrol. 180, 251-266.

Rowe, L.K., 2003. Land use and water resources: a comparison of streamflow from New Zealand catchments with different vegetation covers. Landcare Research Contract Report 6. Landcare Research, Lincoln.

Schulze, R.E., George, W.J., 1987. A dynamic, process-based, user-oriented model of forest effects on water yield. Hydrol. Process. 1, 293-307.

Schulze, R.E., Scott-Shaw, C.R., Nanni, U.W., 1978. Interception by Pinus patula in relation to rainfall parameters. J. Hydrol. 36, 393-396.

Scott, D.F., Lesch, W., 1997. Streamflow responses to afforestation with Eucalyptus grandis and Pinus patula and to felling in the Mokobulaan experimental catchments, South Africa. J. Hydrol. 360-377.

Smith, C.M., 1992. Riparian afforestation effects on water yields and water quality in pasture catchments. J. Environ. Qual. 21, 237-245.

USDI Bureau of Reclamation, 2001. Water Measurement Manual. US Department of the Interior, $317 \mathrm{pp}$.

Vargas, O.R., Zuluaga, S., 1986. Clasificación y ordenación de comunidades vegetales de páramo. Perez Arbelaezia 1, 125-143.

Wada, K., 1985. The distinctive properties of Andosols. Adv. Soil Sci. 2, 174 223

Zhang, L., Dawes, W.R., Walker, G.R., 2001. Response of mean annual evapotranspiration to vegetation changes at catchment scale. Water Resour. Res. 37, 701-708. 